\title{
Ethoxyresorufin 0-deethylase (EROD) activity in the liver of dab (Limanda limanda L.) and flounder (Platichthys flesus L.) from the German Bight. EROD expression and tissue contamination
}

Received: 14 April 1999 / Received in revised form: 10 July 1999 / Accepted: 15 July 1999

\begin{abstract}
Ethoxyresorufin O-deethylase (EROD) activity was measured in the liver of dab (Limanda limanda) and flounder (Platichthys flesus) from the German Bight (southern North Sea) and compared with muscle and liver polychlorinated biphenyl (PCB) concentrations in an attempt to relate EROD activity to PCB body burden. In none of the different datasets (species-, tissue- or matrixdependent) was a significant $(P<0.05)$ correlation between PCB tissue contamination and EROD activity found. Yet EROD activity was significantly correlated with polycyclic aromatic hydrocarbons (PAH) levels (phenanthrene, fluoranthene, pyrene) in muscle tissue, indicating a possible dependence of EROD expression on other ubiquitous organic contaminants, thus making it a suitable biomarker for general pollution.
\end{abstract}

Key words. Ethosyresorufin O-deethylase - Limanda limanda $\cdot$ Platichthys flesus · German Bight · PCB burden

\section{Introduction}

The induction of cytochrome P450 1A enzyme activity in the liver of fish, also known as mixed-function oxygenase (MFO) activity, is an experimentally well-documented biochemical reaction of fish to organic contaminants such as polynuclear aromatic hydrocarbons (PAHs), co-planar polychlorinated biphenyls (PCBs) and chlorinated dibenzo-dioxins and dibenzofurans (CDD, CDF) (Addison and Edwards 1988; Stegemann et al. 1988; Galgani et al. 1991). Induction of MFO activity is commonly determined by measuring the activity of the ethoxyresorufin O-deethylase (EROD). It has been proposed as one of the parameters to be routinely determined in the Biological Effects Monitoring Programme of the North Sea in the framework of the Quality Status

H. v. Westernhagen $(\bullet) \cdot$ G. Krüner $\cdot$ K. Broeg

Biologische Anstalt Helgoland,

Alfred Wegener Institut für Polar- und Meeresforschung,

Notkestrasse 31, D-22607 Hamburg, Germany

e-mail: vwesternhagen@meeresforschung.de
Report and the Joint Monitoring Programme, with particular reference as a biomarker for exposure to planar environmental contaminants (Payne et al. 1987; Goksøyr and Förlin 1992; Sleiderink and Boon 1995).

Although from field studies circumstantial evidence of a correlation between PCB tissue concentrations in fish and EROD activity exists (Addison and Edwards 1988; Sleiderink and Boon 1995), a causal relationship between the two could not be established. In view of the considerable seasonal variation of EROD activity in the liver of fish (Lange et al. 1992; Krüner and Westernhagen 1995), we attempted to define whether there exists a tissue concentration-depending correlation between PCB contamination and the measured EROD activity in the two flatfish species dab, Limanda limanda, and flounder, Platichthys flesus, from different sites in the German Bight.

\section{Material and methods}

Mature male and female dab and flounder were sampled by bottom trawl in the southern North Sea during several cruises (February 1992; March/April 1992; July 1993; February 1994; June 1994; September 1994, 1995; January 1996; October 1996; April 1997; September 1997). Sampling locations and general areas of collection are indicated in Fig. 1.

Immediately after capture fish were sacrificed by a blow on the head and livers were excised. Samples were immediately frozen in cryo tubes in liquid nitrogen for later determination of EROD activity and chlorinated hydrocarbon analysis. In addition, muscle tissue was deep frozen $\left(\right.$ at $\left.-25^{\circ} \mathrm{C}\right)$ for the analysis of chlorinated hydrocarbons and PAHs whenever needed. The preparation of microsomes from liver tissue was performed according to Andersson et al. (1985). The liver (0.5-0.75 g) was homogenised in four volumes of $0.1 \mathrm{M}$ sodium phosphate-buffer including $0.15 \mathrm{M}$ potassium chloride ( $\mathrm{pH}$ 7.4). Homogenates were centrifuged at $10000 \mathrm{~g}$ for $20 \mathrm{~min}$ and the resulting supernatants were centrifuged at

$105000 \mathrm{~g}$ for $60 \mathrm{~min}$. EROD activity was measured as production of resorufin per minute, using the fluorometric method according to Burke and Mayer (1974). Total and microsomal protein content were measured according to Lowry et al. (1951).

Chlorinated biphenyls (CB) congeners and other chlorinated hydrocarbons were analysed by a commercial laboratory employing gel chromatography (GPC Autoprep 1002 B filled with BioBeads SX-3) and capillary gas chromatography with electron cap- 
Fig. 1 Locations and areas of sampling sites for dab (Limanda limanda) and flounder (Platichthys flesus) in the southern North Sea. $H$ Helgoland Tiefe Rinne $E$ Eider $C$ Cuxhaven/Elbe $S$ Spiekeroog; 1-5 areas sampled for analysed fish

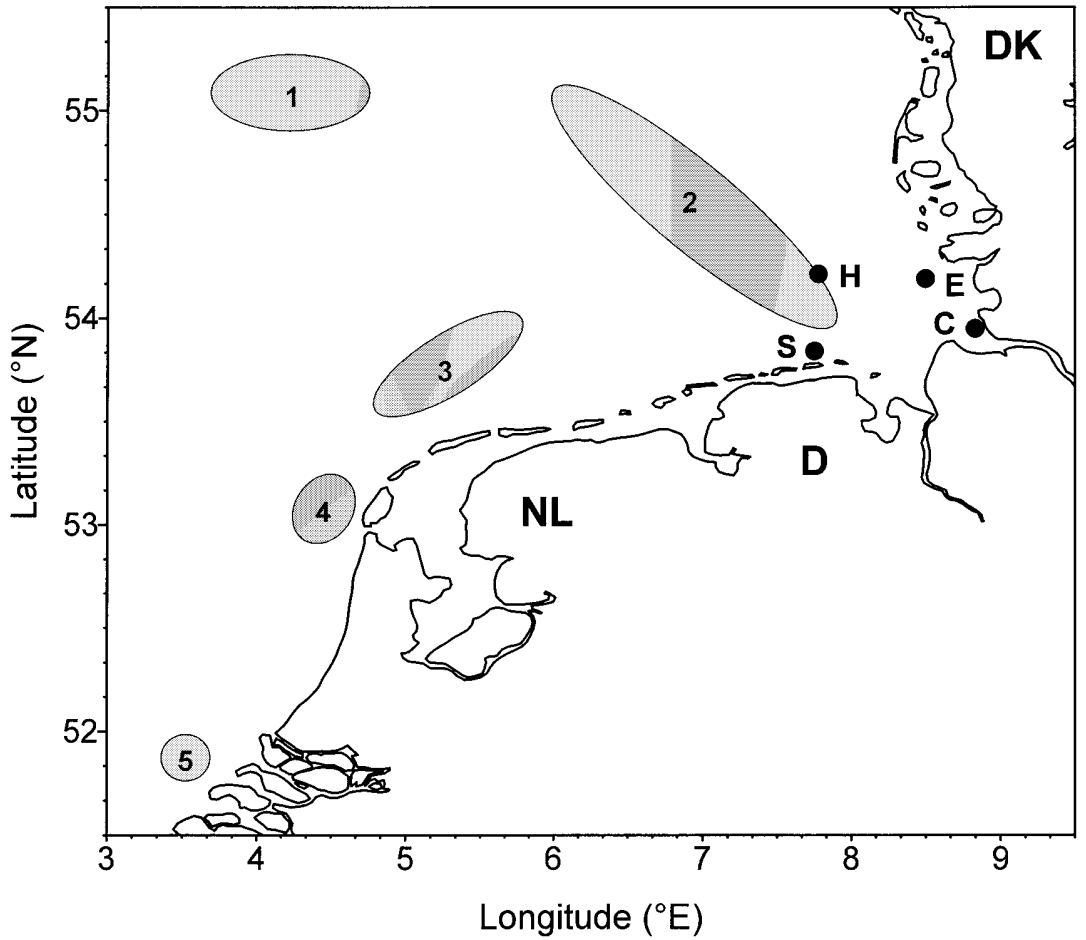

Table 1 Median values and quartiles (in brackets) for PCBA60 concentration (ng $\mathrm{g}^{-1}$ lipids) in liver and muscle tissue of dab (Limanda limanda) and flounder (Platichthys flesus) from the southern North Sea. nd: No data

\begin{tabular}{lllll}
\hline PCBA60 & Liver (lipid) & Liver (wet wt.) & Muscle (lipid) & Muscle (wet wt.) \\
\hline Dab male & $1783(488)$ & $459(162)$ & nd & nd \\
Dab female & $1871(42)$ & $240(1.7)$ & nd & nd \\
Flounder male & $9849(5450)$ & $589(218)$ & $4750(456)$ & $37(5.6)$ \\
Flounder female & $9371(2082)$ & $400(118)$ & $4200(1433)$ & $42(14.3)$ \\
\hline
\end{tabular}

ture detection (GC-ECD ${ }^{63} \mathrm{Ni}$ ) on a Fisons Instruments HRGC Mega 2 Series on a fused silica capillary fitted with a $60-\mathrm{m}$ DB-5 column. Frozen tissue was homogenised with an Ultra Turrax and mixed with quartz sand and $\mathrm{Na}_{2} \mathrm{SO}_{4}$. The organochlorines were then separated from the tissue powder using a solvent mixture of cyclohexane/aceton (2:1) for $30 \mathrm{~min}$. Before the preparation of the final extract a clean-up process employing gel chromatography was applied.

\section{Results and discussion}

In Fig. 2 EROD activity in male and female dab and flounder from the southern North Sea is presented. As demonstrated already in a previous investigation by Krüner and Westernhagen (1995) the expression of EROD activity in dab was strongly dependent on the season, with highest values between April and July and low EROD activity from September to February/March. During sexual maturation in dab, differences between sexes were significant in February and April, with higher EROD activity measured in males. In July and September, there were no differences in the expression of EROD activity between sexes. These findings correspond to those of Arukwe and Goksøyr (1997),Sleiderink et al. (1995a), and Förlin and Haux (1990) in dab, and Edwards et al. (1988) in winter flounder (Pseudopleuronectes americanus), although Lange et al. (1992) did not find significant sex-dependent differences in EROD activity in North Sea dab, probably due to small sample size. For flounder, no significant differences between seasons or the sex of the fish were noticeable. Highest mean values were measured for both sexes in April (0.51 male; 0.41 female). Differences were small and not significant. The apparent lack of a seasonal dependence in the expression of EROD activity in flounder has already been mentioned by Eggens et al. (1995) for flounder from the Dutch Wadden Sea.

Since in most analyses, concentrations of the ERODinducing co-planar congeners CB77, CB126 and CB169 were below detection limits, $\mathrm{PCB}$ was calculated as PCBA60 [(CB138+CB153+CB180)/0.3] to give an indirect indication of the amount of inducing-PCB present in the animals. A similar approach has been practised by Sleiderink et al. (1995a) who used the sum of 7 CBs as a reference for contaminant with regard to EROD activity. Residue concentrations for PCBA60 ranged from below 
a

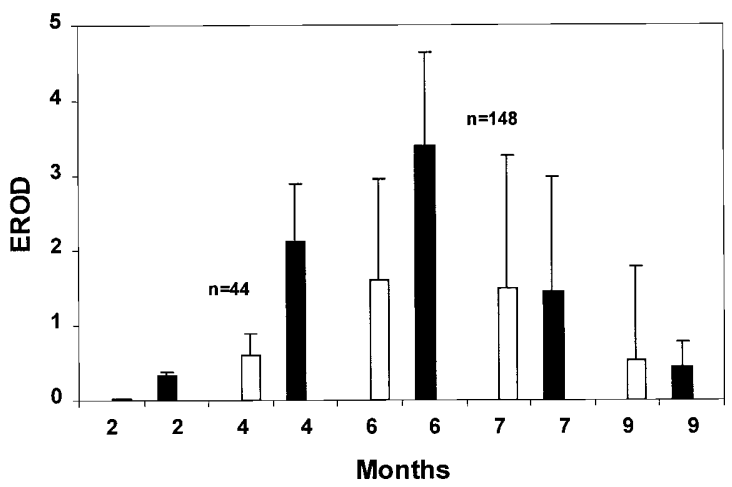

b

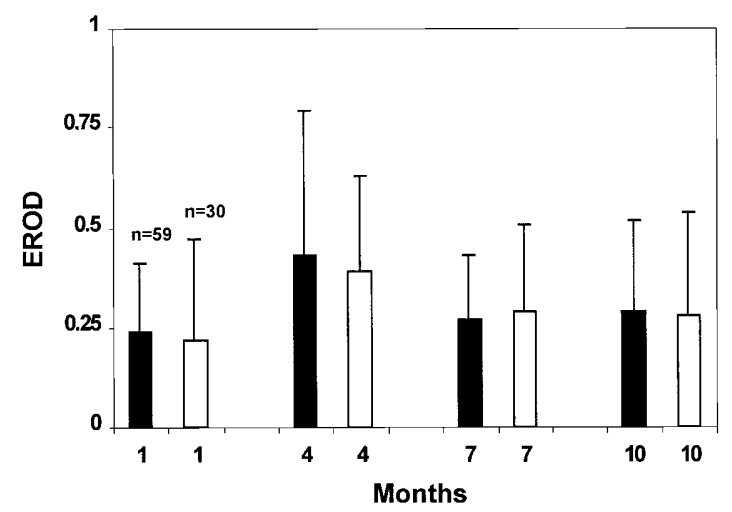

Fig. 2 Seasonal differences in hepatic EROD activity $\left(\mathrm{nmol} \mathrm{min} \mathrm{m}^{-1}\right.$ $\mathrm{mg}$ prot $^{-1}$ ) in dab (Limanda limanda), and flounder (Platichthys flesus) from the southern North Sea. a dab; b flounder; $n$ dablowest (44) and highest (148); $n$ flounder-lowest (30) and highest (59) number of specimens in the respective groups analysed. Black columns: male; white columns: female

100 to above $120000 \mathrm{ng} \mathrm{g}^{-1}$ soluble lipids in liver and up to $180000 \mathrm{ng} \mathrm{g}^{-1}$ when based on muscle fat. On a wet weight basis, PCBA60 tissue concentrations ranged from 10 to about $2300 \mathrm{ng} \mathrm{g}^{-1}$. Levels of PCB in dab were similar to those reported by Büther (1988) for this species in the southern North Sea, but up to two orders of magnitude higher than reported by Sleiderink and Boon (1995) and Sleiderink et al. (1995b) for the same area. Lipidbased liver burden of PCBA60 in flounder at times was up to one order of magnitude higher than in dab (Fig. 3), reflecting the differences in liver fat of the two species (flounder: mean 3.6\%; dab: mean 24.5\%), but was in a similar range for both species when body burden was considered on a wet weight basis (see Table 1 for medians and quartiles of PCBA60 content in both species). EROD activity in flounder was rather low throughout, rarely exceeding $1.0 \mathrm{nmol}^{-1} \mathrm{~min}^{-1} \mathrm{mg}^{-1}$ protein, while EROD induction in dab was generally much higher, $50 \%$ of the measured values exceeding $1.0 \mathrm{nmol} \mathrm{min}{ }^{-1} \mathrm{mg}^{-1}$ protein with maximum values above $4.0 \mathrm{nmol} \mathrm{\textrm {min } ^ { - 1 }}$ $\mathrm{mg}^{-1}$ protein in dab. In fact, results of Besselink et al. (1996) indicate that flounder is not sensitive to PCB exposure. There were no significant differences in tissue contamination between either sex of both species (see Fig. 4 for dab).

EROD activity was not correlated with PCB content in either species or sex, irrespective of the basis used for the calculation of PCBA60, lipids or wet weight. This picture did not change when only data for dab from the season with maximum EROD expression (April-July) were considered (Fig. 4). In the latter dataset the correlation between PCBA60 and EROD activity was low $(r=0.205)$, and this situation prevailed when individual CBs such as CB153 were considered, as has also been practised by Sleiderink et al. (1995a).

The above-mentioned findings are in contrast to the general understanding that organochlorine compounds like planar PCBs, are potent inducers of EROD activity (Goksøyr and Husøy 1998), and results obtained by other authors comparing PCB residues in fish liver with EROD activity (Jørgensen et al. 1999). Addison and Edwards (1988), for instance, noted that in flounder from a Norwegian Fjord EROD activity was significantly positively correlated with total PCBs; also Sleiderink and Boon (1995) and Sleiderink et al. (1995a) investigated the response of North Sea dab towards environmental chemicals and showed that muscle tissue PCB of North Sea dab (either as total PCBs or as CB153) was well correlated with EROD. However, when the highly polluted coastal stations were omitted from the statistical analysis of their data, no significant correlations between chemical body burden and biochemical (EROD) parameters were observed, indicating that an observed correlation may not have been the result of a causal relationship. Similarly, in caging experiments with flounder and cod (Gadus morhua) exposed to polluted sediments, hepatic CYP1A induction was not correlated with PCB tissue levels (Goksøyr et al. 1989), which may also be an indication that there are species-specific differences in the CYP1A system towards PCBs.

Thus, the situation regarding the role of $\mathrm{PCB}$ as EROD inducers in the environment remains somewhat contradictory, and the question remains: why is PCB or some congeners some times well correlated with EROD activity and sometimes not? One of the reasons for this apparent inconsistency in the induction of EROD activity may be a species-dependent expression of EROD activity on the basis of different distribution patterns in the respective fish species, as has been demonstrated experimentally by Bernhoft et al. (1994) for rainbow trout and cod, cod having a lower potential for induction of the hepatic xenobiotic system than trout. A similar difference may prevail in dab and flounder, explaining observed differences in EROD expression at comparable PCB contamination levels (see Fig. 3), since, after i.p. injection of flounder with Clophen A50, Besselink et al. (1996) stated that, for instance, floun- 
Fig. 3 EROD activity (nmol $\mathrm{min}^{-1} \mathrm{mg}^{-1}$ protein) in relation to liver (liv.)PCB ( ng g $^{-1}$ lipids) in dab and flounder from the southern North Sea (note logarithmic scale on $y$-axis)

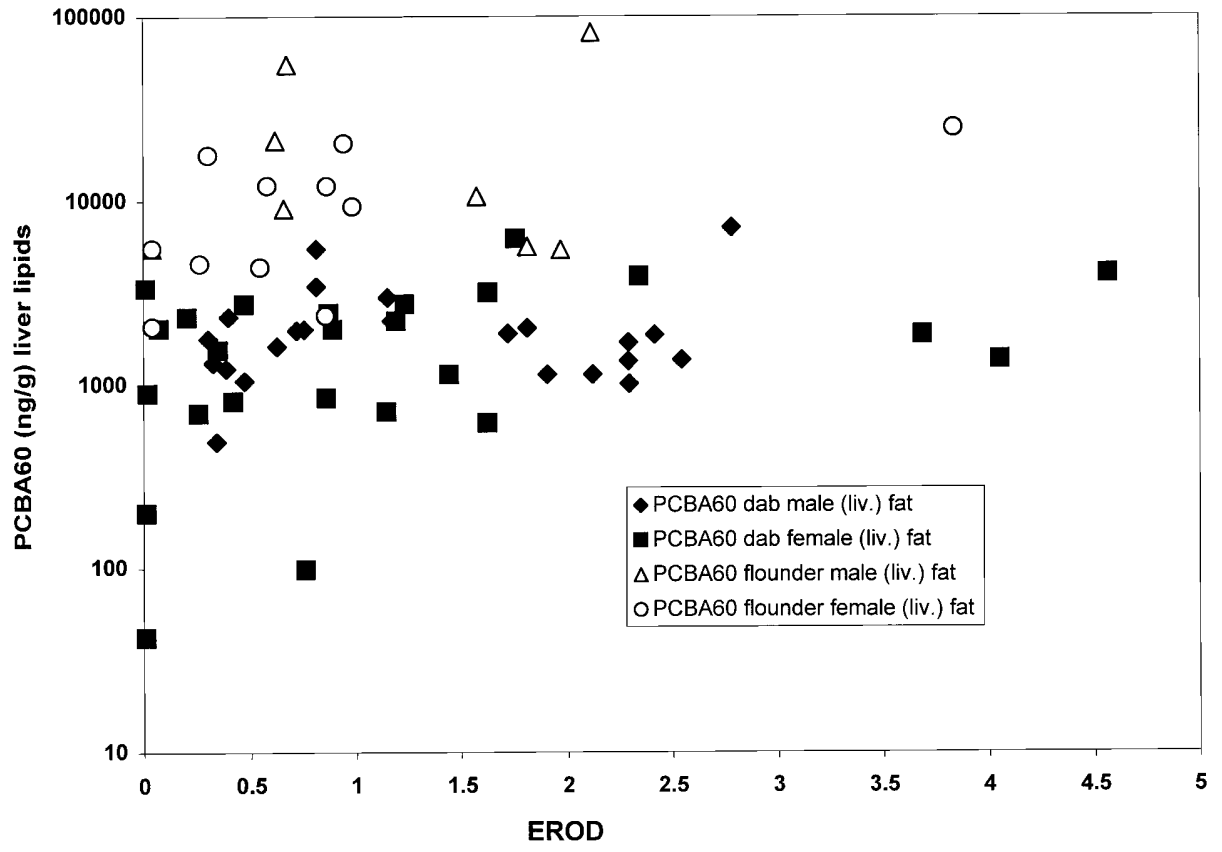

Fig. 4 EROD activity (nmol min $^{-1} \mathrm{mg}^{-1}$ protein) in dab (Limanda limanda) during the season of maximum expression (April-July) in relation to PCB A60 content in liver (liv.)

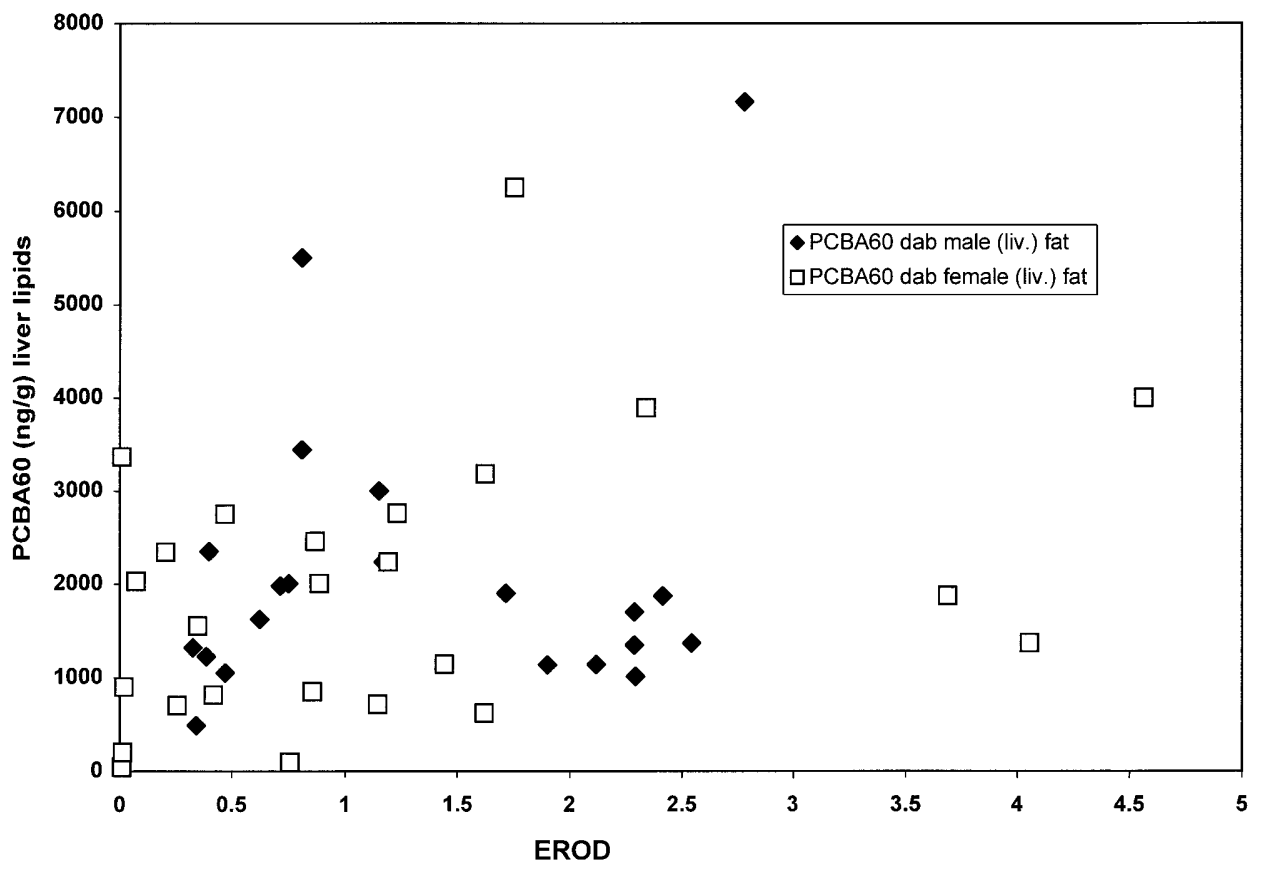

der is not a species sensitive to PCB exposure, which is consistent with the findings of Eggens et al. (1996). However, also dab may not be induced consistently well by PCBs and may need relatively high concentrations, as suggested when looking at the levels of PCBA60 able to induce EROD activity in Figs. 3 and 4. It can be seen that above a PCBA60 concentration of about $1000 \mathrm{ng} \mathrm{g}^{-1}$ lipids, EROD activity is above $1.5 \mathrm{nmol} \mathrm{min} \mathrm{mg}^{-1} \mathrm{mg}^{-1}$ protein, which is considered a strong induction, following the suggestions of Krüner et al. (1996), who consider EROD activities above 0.8 nmol $\mathrm{min}^{-1} \mathrm{mg}^{-1}$ protein indicative of a strong pollution influence.

Another factor to be considered may be temperature. A strong influence of temperature on EROD activity has been shown to exist, although the temperature effect does not necessarily show a causal relationship but is rather coincidental with the state of maturity the fish have reached (see also Lange et al. 1998). Krüner and Westernhagen (1995) showed experimentally that turbot 


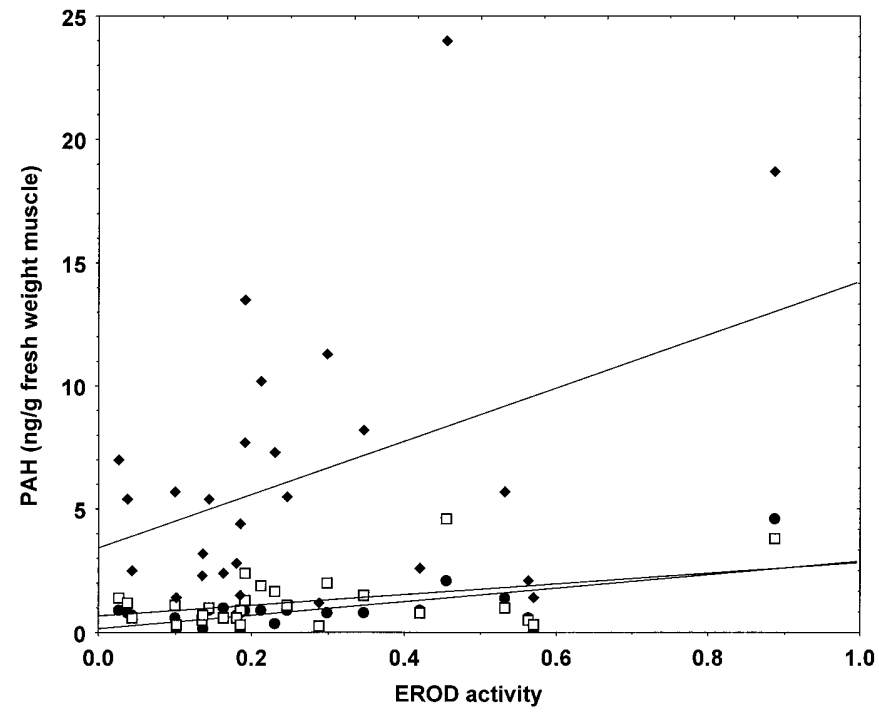

Fig. 5 EROD activity (nmol $\mathrm{min}^{-1} \mathrm{mg}^{-1}$ protein) in dab (Limanda limanda) in relation to the tri- and polyaromatic compounds phenanthren $(\bullet)$, fluoranthen $(\square)$ and pyren $(\diamond)$ in muscle tissue (ng kg-1 fresh wt)

(Scophthalmus maximus) displayed higher EROD activity with increasing temperatures, while Lange et al. (1992) claimed higher EROD activity at lower temperatures in dab, and Sleiderink et al. (1995b) even stated that in their investigations of EROD in North Sea dab the effect of water temperature was dominant over the effect of PCB contamination; EROD activity being higher at low temperatures. Thus, differences in water temperature between sampling stations may have obscured effects of PCB contamination on EROD activity or an existing reaction may even have been suppressed by chemicals such as tributyltin (TBT) (Fent and Stegeman 1993; Morcillo and Porte 1997) or tetrachlorobiphenyl (TCB), as found out by Monosson and Stegemann (1991) in winter flounder (Pseudopleuronectes americanus).

After all, from the different chlorinated biphenyls only CB77 and CB126 are EROD inducers and they occur only in very low concentrations, giving reason to assume that their effect may not always be satisfactorily expressed. From previous investigations (Krüner et al. 1996) on the expression of EROD activity in dab and the occurrence of various pollutants, we know that there are a number of substances that co-occur with dominant pollution-indicating tracers (such as PCBs), thus giving the impression that they themselves are the causes of particular events. This was, for instance, demonstrated in the induction of EROD activity in feral eel (Anguilla anguilla) by PCB and a number of non-inducing co-occurring chlorinated hydrocarbons such as DDT and others (Oost et al. 1997).

In this respect it should be noted that particularly PAHs are considered to indicate pollution, resulting from various kinds of industrial and anthropogenic activities, and given that they have been proven experimentally and in the field to be potent EROD inducers (Addison and Payne 1986; Van Veld et al. 1990; Goksøyr and Förlin 1992; Stagg et al. 1995) we have analysed the PAHs in muscle of flounder in the course of this study. The relationship between three major PAHs (phenanthrene, fluoranthene, pyrene) and EROD activity is shown in Fig. 5. A significant concentration-dependent correlation between EROD activity and concentrations of these triand polycyclic substances was found, indicating that in the southern North Sea possibly substances other than PCB may be the main inducers of EROD activity in fish. This statement is also supported by Sleiderink et al. (1993) and by the results of experiments conducted by Livingstone et al. (1993) to induce EROD activity in dab. Their results indicate a significant EROD activity induction of PCB always in conjunction with the simultaneous occurrence of considerable PAH concentrations. The effectiveness of PAH metabolites of the phenanthrene-type to induce EROD activity has also been confirmed by Miller et al. (1999) through the use of quantitative RT-PCR measurements in the Antarctic fish Trematomus bernacchii.

Thus, in conclusion we may summarise that expression of EROD activity in dab is about 4 times that recorded in flounder. While PCB is not a good EROD inducer in dab and even less so in flounder, PAHs are. In dab a pronounced seasonal fluctuation of the EROD activity together with a sex dependent expression during the reproductive period has to be taken into consideration when employing this biomarker for environmental quality assessment. In flounder seasonal differences are less pronounced and there are no significant differences between male and female individuals. Due to relative low response and variabiliy of EROD activity in flounder, its usefulness for environmental impact assessment remains limited in this species. Yet results obtained by Broeg et al. (this issue) using EROD activity in flounder were in good agreement with the other biomarkers used during the study.

\section{References}

Addison RF, Edwards AJ (1988) Hepatic microsomal mono-oxygenase activity in flounder Platichthys flesus from polluted sites in Langesundfjord and from mesocosms experimentally dosed with diesel oil and copper. Mar Ecol Progr Ser 46: $51-54$

Addison RF, Payne JF (1986) Assessment of hepatic mixed function oxidase induction in winter flounder (Pseudopleuronectes americanus) as a marine petroleum pollution monitoring technique, with an appendix describing practical field measurements of MFO activity. Can tech Rep Fish Aquat Sci 1505:1-34

Andersson T, Pesonen M, Johansson C (1985) Differential induction of cytochrome P-450-dependent monooxygenase, epoxide hydrolase, glutathione transferase and UDP glucuronosyl transferase activities in the liver of the rainbow trout by BNF of Clophen A50. Biochem Pharmacol 34:3309-3314

Arukwe A, Goksøyr A (1997) Changes in three hepatic cytochrome P450 subfamilies during a reproductive cycle in turbot (Scophthalmus maximus L.). J Exp Biol 277:313-325 
Bernhoft A, Hektoen H, Skaare JU, Ingebrigtsen K (1994) Tissue distribution and effects on hepatic xenobiotic metabolism enzymes of 2,3,3',4,4'-pentachlorobiphenyl (PCB-105) in cod (Gadus morhua) and rainbow trout (Oncorhynchus mykiss). Environ Pollut 85:351-359

Besselink HT, Van Beusekom S, Poex E, Vethaak AD, Koeman JH, Brouwer A (1996) Low hepatic 7-ethoxyresorufin-O-deethylase (EROD) activity and minor alterations in retinoid and thyroid hormone levels in flounder (Platichthys flesus) exposed to the polychlorinated biphenyl (PCB) mixture, Clophen A50. Environ Pollut 92:267-274

Burke MD, Mayer RT (1974) Ethoxyresorufin: direct fluorimetric assay of a microsomal O-dealkylation which is preferentially inducible by 3-methyl-cholanthrene. Drug Metab Disposit 2:583-588

Büther H (1988) Distribution of chlorinated organic compounds in livers of dab (Limanda limanda) of the southern and central North Sea. Mitt Geol-Paläont Inst. Univ Hamburg 65:497-541

Edwards AJ, Addison RF, Willis DE, Renton KW (1988) Seasonal variation of hepatic mixed function oxidases in winter flounder (Pseudopleuronectes americanus). Mar Environ Res 26: 299-309

Eggens ML, Bergman A, Vethaak (1995) Seasonal variation of hepatic EROD activity in flounder (Platichthys flesus) in the Dutch Wadden Sea. Mar Environ Res 39:231-234

Eggens ML, Opperhuizen A, Boon JP (1996) Temporal variation of CYP 1 A indices, $\mathrm{PCB}$ and 1-OH pyrene concentration in flounder, Platichthys flesus, from the Dutch Wadden Sea. Chemosphere 33: 1579-1596

Fent K, Stegemann JJ (1993) Effects of tributyltin in vivo on hepatic cytochrome P450 forms in marine fish. Aquat Toxicol 24:219-240

Förlin L, Haux C (1990) Sex differences in hepatic cytochrome P450 monooxygenase activities in rainbow trout during an annual reproductive cycle. J Endocrinol 124:207-213

Galgani F, Bocquene G, Lucon M, Grzebyk D, Letrouit F, Claisse D (1991) EROD measurements in fish from the northwest part of France. Mar Pollut Bull 22:494-500

Goksøyr A, Förlin L (1992) The cytochrome P-450 system in fish, aquatic toxicology and environmental monitoring. Aquat Toxicol 22:287-311

Goksøyr A, Husøy AM (1998) Immunochemical approaches to studies of CYP1A localization and induction by xenobiotics in fish. In: Braunbeck T, Hinton DE, Streit B (eds) Fish Ecotoxicology. pp. 165-202 Birkhäuser, Basel

Goksøyr A, Husøy AM, Larsen HE, Klungsøyr J, Wilhelmesen S, Brevik EM, Andersson T, Celander M, Pesonen M, Förlin L (1989) Evaluation of biochemical responses to environmental contaminants in flatfish from the Hvaler Archipelago in Norway. Mar Environ Res 28:51-55

Jørgensen EH, Bye BE, Jobling M (1999) Influence of nutritional status on biomarker responses to $\mathrm{PCB}$ in the Arctic charr (Salvelinus alpinus). Aquat Toxicol 44:233-244

Krüner G, Westernhagen H von (1995) Hepatic ethoxyresorufin O-deethylase (EROD) activity in the liver of dab (Limanda limanda L.) from the German Bight. I. Seasonal and regional variations. Z Angew Zool 81:43-54

Krüner G, Janssen D, Westernhagen H von (1996) Wissenschaftliche Grundlagen sowie Beschaffung und Bewertung von Daten für das Biologische Monitoring der Nordsee. Ber Biol Anst Helgoland 11:1-82

Lange U, Jedamski-Grymlas J, Siebers D, Karbe L (1992) Ethoxyresorufin O-deethylase and cytochrome P450 in the liver of dab (Limanda limanda L.) from the central and southern North Sea. Mar Pollut Bull 24:446-451
Lange U, Saborowski R, Siebers D, Buchholz F, Karbe L (1998) Temperature as a key factor determining the regional variability of the xenobiotic-inducible ethoxyresorufin-O-deethylase activity in the liver of dab (Limanda limanda). Can J Fish Aquat Sci 55:328-338

Livingstone DR, Lemaire P, Matthews A, Peters L, Bucke D, Law RJ (1993) Pro-oxidant, antioxidant and 7-ethoxyresorufin O-deethylase (EROD) activity response in liver of dab ( Limanda limanda) exposed to sediment contaminated with hydrocarbons and other chemicals. Mar Pollut Bull 26:602-606

Lowry OH, Rosebrough NJ, Farr AL, Randall RJ (1951) Protein measurement with the folin phenol reagent. J Biol Chem 193:265-275

Miller HC, Mills GN, Bembo DG, Macdonald JA, Evans CW (1999) Induction of cytochrome P4501 A (CYP1 A) in Trematomus bernacchii as an indicator of environmental pollution in Antarctica: assessment by quantitative RT-PCR. Aquatic Toxicol 44:183-193

Monosson E, Stegemann JJ (1991) Cytochrome P450 E (P450IA) induction and inhibition in winter flounder by 3,3',4,4'-tetrachlorobiphenyl: Comparison of response in fish from Georges Bank and Narrangansett Bay. Environ Toxicol Chem 10: 765-774

Morcillo Y, Porte C (1997) Interaction of tributyl- and triphenyltin with the microsomal monooxygenase system of molluscs and fish from the western Mediterranean. Aquat Toxicol 38:3546

Oost van der R, Vindimian E, Brink PJ van der, Satumalay K, Heida H, Vermeulen NPE (1997) Biomonitoring aquatic pollution with feral eel (Anguilla anguilla). III. Statistical analyses of relationships between contaminant exposure and biomarkers. Aquat Toxicol 39:45-75

Payne JF, Fancey LL, Rahimtula AD, Porter EL (1987) Review and perspective on the use of mixed-function oxygenase enzymes in biological monitoring. Comp Biochem Physiol $86 \mathrm{C}: 233-245$

Sleiderink HM, Boon JP (1995) Cytochrome P450 1 A response in North Sea dab, Limanda limanda, from offshore and coastal sites. Mar Pollut Bull 30, 660-666

Sleiderink HM, Boon JP, Everaarts JM (1993) Levels of EROD activity, P450 A1, and sigma P450 in dab (Limanda limanda) from the southern North Sea in relation to PCB concentrations - preliminary results. Mar Environ Res 35:201-202

Sleiderink HM, Oostingh I, Goksøyr A, Boon JP (1995a) Sensitivity of cytochrome P450 1 A induction in dab (Limanda liman$d a$ ) of different age and sex as a biomarker for environmental contaminants in the southern North Sea. Arch Environ Contam Toxicol 28:423-430

Sleiderink HM, Beyer J, Scholtens E, Goksøyr A, Nieuwenhuize J, Van Liere JM, Everaarts JM, Boon JP (1995b) Influence of temperature and polyaromatic contaminants on CYP1 A levels in North Sea dab (Limanda limanda). Aquat Toxicol 32: 189-209

Stagg RM, McIntosh A, Mackie P (1995) Elevation of hepatic monooxygenase activity in dab (Limanda limanda) in relation to environmental contamination with petroleum hydrocarbons in the northern North Sea. Aquat Toxicol 33:245-264

Stegemann JJ, Woodin BR, Goksøyr A (1988) Apparent cytochrome P-450 induction as an indication to environmental chemicals in the flounder Platichthys flesus. Mar Ecol Progr Ser 46:55-60

Van Veld PA, Westbrook DJ, Woodin BR, Hale RC, Smith CL, Huggett RJ, Stegeman JJ (1990) Induced cytochrome P-450 in intestine and liver of spot (Leiostomus xanthurus) from a polycyclic aromatic hydrocarbon contaminated environment. Aquat Toxicol 17:120-131 